JUDICIALIZING EVERYTHING? 
This page intentionally left blank 


\section{JUDICIALIZING EVERYTHING?}

The Clash of Constitutionalisms in Canada, New Zealand, and the United Kingdom

MARK S. HARDING

UNIVERSITY OF TORONTO PRESS

Toronto Buffalo London 
(C) University of Toronto Press 2022

Toronto Buffalo London

utorontopress.com

Printed in the U.S.A.

ISBN 978-1-4875-2848-5 (cloth)

ISBN 978-1-4875-2850-8 (EPUB)

ISBN 978-1-4875-2849-2 (PDF)

\section{Library and Archives Canada Cataloguing in Publication}

Title: Judicializing everything? : the clash of constitutionalisms in Canada, New Zealand, and the United Kingdom / Mark S. Harding.

Names: Harding, Mark S., author.

Description: Includes bibliographical references and index.

Identifiers: Canadiana (print) 20210366591 | Canadiana (ebook) 20210366893 |

ISBN 9781487528485 (cloth) | ISBN 9781487528508 (EPUB) |

ISBN 9781487528492 (PDF)

Subjects: LCSH: Constitutional law - Commonwealth countries. | LCSH: Civil rights - Commonwealth countries.

Classification: LCC KD5025 .H37 2022 | DDC 342/.11241 - dc23

We wish to acknowledge the land on which the University of Toronto Press operates. This land is the traditional territory of the Wendat, the Anishnaabeg, the Haudenosaunee, the Métis, and the Mississaugas of the Credit First Nation.

This book has been published with the help of a grant from the Federation

for the Humanities and Social Sciences, through the Awards to Scholarly

Publications Program, using funds provided by the Social Sciences and Humanities Research Council of Canada.

University of Toronto Press acknowledges the financial support of the Government of Canada, the Canada Council for the Arts, and the Ontario Arts Council, an agency of the Government of Ontario, for its publishing activities.

Canada Council for the Arts
Conseil des Arts du Canada

\section{Funded by the


For Margaret Joan and Jack Arthur Harding 
This page intentionally left blank 